\title{
INTERCONNECTIVITIES BETWEEN HAZARD, DAMAGE, AND SHORELINE TYPE: LESSONS LEARNED FROM HURRICANE IRMA'S IMPACT ON THE FLORIDA KEYS
}

Tori Tomiczek, United States Naval Academy, vjohnson@usna.edu

Brittany Webbmartin, United States Naval Academy, m186888@usna.edu

Steven Scyphers, Northeastern University, s.scyphers@northeastern.edu

Kiera O'Donnell, Northeastern University, odonnell.ki@husky.neu.edu

Kelsi Furman, Northeastern University, furman.ke@husky.neu.edu

\section{IMPORTANCE}

The 2017 Atlantic hurricane season had 17 named storms, 10 hurricanes, and 6 major hurricanes, generating over 226 units of accumulated cyclone energy (ACE), a measure used by the National Oceanographic and Atmospheric Association (NOAA) that refers to the combined the intensity and duration of a hurricane. These statistics earned the hurricane season's classification as "extremely active," the most active since 2005. Preliminary estimates of damage due to Hurricanes Harvey, Irma, and Maria amount to over $\$ 200$ billion dollars in the United States alone.

Recent studies suggest that the frequency of these highintensity Category 4 and 5 hurricanes is increasing (e.g. Mendelsohn et al., 2012). The 2017 hurricane season may thus be representative of an expected season. Accounting for projected increases in mean sea level, storm impacts may be exacerbated in coastal regions. These trends emphasize the need for effective damage mitigation techniques that improve the robustness and resiliency of coastal communities.

Structures must be designed to not only avoid wave and surge loads, but also resist these forces in the event of a wave impact. Furthermore, creative, cost-effective solutions are required to mitigate waves and surge before they reach developed coastal areas. Thus, engineers require a robust, science-based methodology for predicting details of wave propagation over land and inland effects to ensure life safety and reduce economic loss due to extreme events. While traditional engineering strategies (e.g. seawalls, bulkheads) have been used to prevent coastal erosion and mitigate inland effects of hurricane waves and surge, recent storm events have shown potential of nature and natural based features (e.g. dune vegetation, mangroves, wetlands, salt-marshes, coral reefs, and seagrass) to protect coastal structures during storm events.

\section{HURRICANE IRMA AND FIELD RECONNAISSANCE SURVEY IN KEY WEST AND BIG PINE KEY}

Hurricane Irma was the ninth named storm and fourth hurricane of the 2017 Atlantic Hurricane Season. Hurricane Irma's intensity quickly increased after its formation on 30 August: the storm reached a minimum central pressure of $914 \mathrm{mBar}$, with maximum one-minute sustained wind speeds of $180 \mathrm{mph}(80.5 \mathrm{~m} / \mathrm{s})$ on 6 September 2017 as it approached the Leeward Islands from the tropical Atlantic Ocean. The storm's minimum central pressure was the second most intense and the maximum wind sustained wind speeds were the strongest recorded of the 2017 season. Hurricane Irma made successive landfalls in Barbuda, the Virgin Islands, the Bahamas, and Cuba, losing strength due to landfall interaction. At the time of the storm's landfall on Cudjoe Key at 1300 UTC (0900 local time) on 10

September 2017, Hurricane Irma was a Category 4 storm, with a central pressure of $929 \mathrm{mBar}$ and $130 \mathrm{mph}$ $(58.1 \mathrm{~m} / \mathrm{s})$ one-minute sustained winds. The storm made a final landfall on Marco Island, FL, before losing strength and dissipating on 13 September, 2017. Hurricane Irma caused significant damage in many Caribbean Islands including severe property damage and devastating loss of life. In the United States alone, the storm was responsible for millions of power outages, boil water orders, as well as 102 known deaths. The total property damage estimated due to the storm exceeded \$50 billion USD (2017), making Hurricane Irma the fifth costliest storm in US history (NHC, 2017).

A post storm reconnaissance survey was conducted from 5-9 October to evaluate damage to residential structures and shorelines in Key West and Big Pine Key. The reconnaissance team was composed of students and researchers from the United States Naval Academy and Northeastern University. For each sampled location, the team recorded structural characteristics (e.g. elevation of lowest horizontal structural member, number of stories, foundation type, single family or multi-family), location characteristics (latitude and longitude), and damage characteristics (damage state, georeferenced photographs for data visualization and validation). Damage states were evaluated for residential structures using component-based damage descriptions (Table 1). Shoreline archetypes were defined for waterfront structures based on NOAA C-CAP classifications, and based on observations and permitting data, damage descriptions for defined for each shoreline archetype, as shown in Table 2.

Table 1- Component-based damage assessments

\begin{tabular}{|c|c|c|c|c|c|}
\hline Component & 0 & 1 & 2 & 3 & 4 \\
\hline $\begin{array}{l}\text { Roof } \\
\end{array}$ & $\begin{array}{l}\text { - No } \\
\text { visible } \\
\text { damage }\end{array}$ & 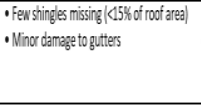 & 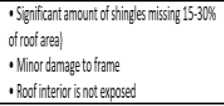 & $\begin{array}{l}\text { - Holes in roof due to debrisor } \\
\text { wind-sheathing is exposed butnot } \\
\text { housse interior }\end{array}$ & $\begin{array}{l}\text { - Largepanttsof roof are missing } \\
\text { or callagsed; Structural damage }\end{array}$ \\
\hline Walls & $\begin{array}{l}\text { - No } \\
\text { visible } \\
\text { damage }\end{array}$ & $\begin{array}{l}\text { - Minor cladding removol (k10\% of 1 wall) } \\
\text { - Small scratches/ aestheticic damage }\end{array}$ & 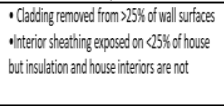 & $\begin{array}{l}\text { - Winor structural wall damagge, } \\
\text { including debris caused holes or } \\
\text { reparirble dangage }\end{array}$ & 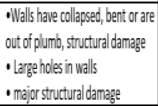 \\
\hline Foundation & $\begin{array}{l}\text { - No } \\
\text { visible } \\
\text { damage }\end{array}$ & $\begin{array}{l}\text { - Sccour r.5.5 feet around foundotion } \\
\text { - Whater makns around foundation } \\
\text { - Structurallysound }\end{array}$ & 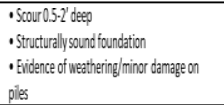 & $\begin{array}{l}\text { - One ple out of plumbi, ar } \\
\text { damagaged } \\
\text { - Scour }>2 \text { deep } \\
\text { - Minor damoge to foundation }\end{array}$ & 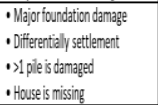 \\
\hline 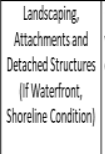 & - No & 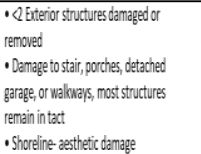 & 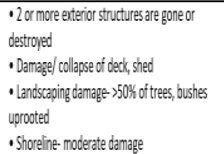 & 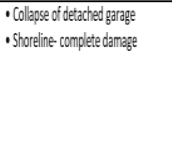 & \\
\hline $\begin{array}{l}\text { Openings: Windous, } \\
\text { Doors, Attached } \\
\text { Garages }\end{array}$ & $\begin{array}{l}\text { - No } \\
\text { visble } \\
\text { damage }\end{array}$ & 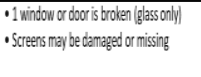 & 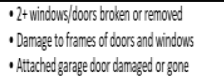 & & \\
\hline Interior & $\begin{array}{l}- \text { - No } \\
\text { visible } \\
\text { damage }\end{array}$ & $\begin{array}{l}\text { Nla fooding } \\
\text { - Winimal/no eridence of rain intrusion. } \\
\text { minor waterdamage in connersor around } \\
\text { windows only } \\
\text { - Minor water damage to interior } \\
\text { furrishings }\end{array}$ & 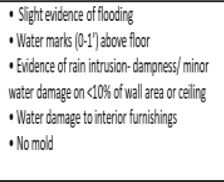 & 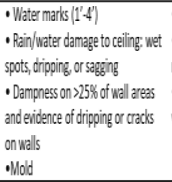 & 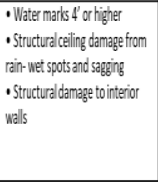 \\
\hline
\end{tabular}


Table 2- Shoreline damage definitions

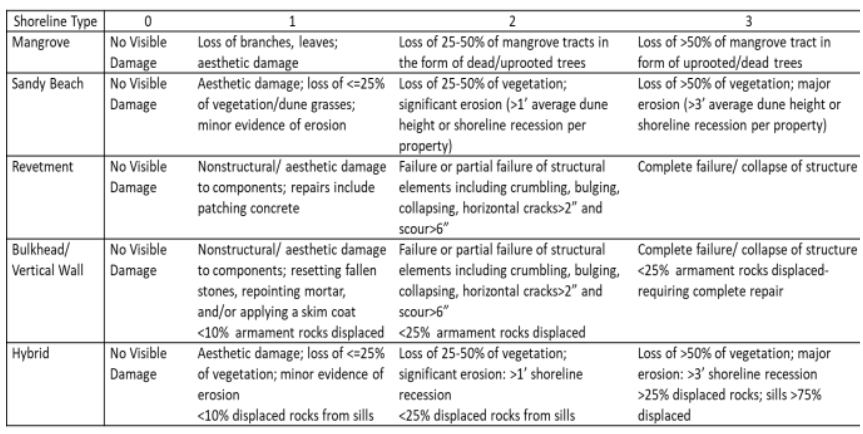

In all, damage assessments were completed for 263 structures and 332 shorelines. Figure 1 depicts each surveyed residence on Key West and Big Pine Key, classified by damage state. In general, more severe damage was observed on Big Pine Key, which was located closer to Hurricane Irma's landfall and therefore experienced more severe storm surge, wave, and wind conditions.

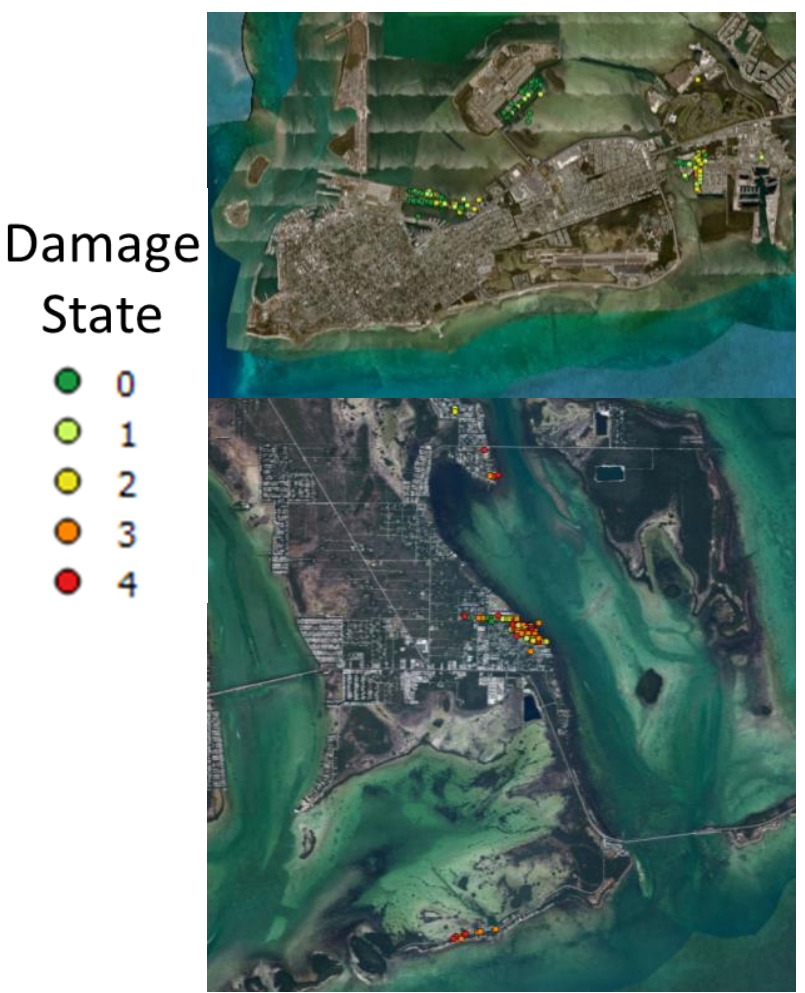

Figure 1: Top- damage to residential structures in (top) Key West and (bottom) Big Pine Key after Hurricane Irma.

\section{RESULTS AND RELATIONSHIP BETWEEN SHORELINE CHARACTERISTIC AND DAMAGE}

Hydrodynamic conditions were extracted from an ADCIRC+SWAN simulation of the storm to obtain the peak inundation depth, wave height, and wind speed at each surveyed location (CERA, 2017). Relationships between hazard intensity, shoreline type, and structural damage were explored as shown in Fig. 2, which plots a structure's damage state against the elevation of the wave crest above the lowest horizontal member of the structure. Figure 2 shows a distinction in damage sustained by structures with wave crests over six feet above the lowest horizontal structural member. While structures with seawall and sandy shorelines typically experienced more severe damage (damage state of 2,3 , or 4 ), structures behind mangrove shorelines and revetments typically sustained less damage. In particular, mangrove shorelines were associated with structures experiencing damage states of 0 (no visible damage) or 1 (minor damage) for all except one sampled location.

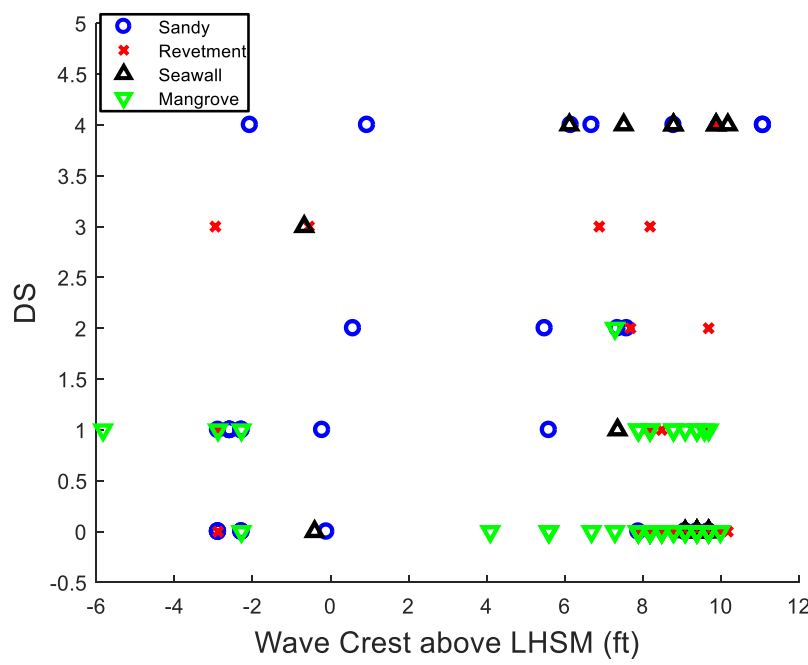

Figure 2: Structural damage state plotted against the elevation of wave crest above the structure's lowest horizontal structural member, classified by shoreline type: sandy beach (blue circles), revetment (red exes), seawall (black upward triangles), and mangrove (green downward triangles).

\section{CONCLUSIONS}

This work represents one of the first investigations of the influence of shoreline type on structural damage during extreme events. Significant interconnectivities exist between shoreline characteristics (e.g. mangrove, sandy beach, hardened) and the nearshore wave environment, and these variable shorelines affect wave and surge transformation over land. Ongoing work is investigating additional relationships between hazard, shoreline characteristic, and shoreline and structural damage using categorical fragility models. Additionally, the influence of shoreline characteristic on nearshore wave reflection and transformation is being characterized using low cost accelerometers. Natural and nature based features have the potential to serve as cost-effective, resilient solutions to coastal hazards, and multidisciplinary efforts are required to better understand relationships between shoreline types, wave characteristics, and coastal resilience.

\section{REFERENCES}

Coastal Emergency Risks Assessment (CERA). 2018. Real-Time Storm Surge and Wave Visualization Tool. 31 January 2018. http://nc-cera.renci.org.

Mendelsohn, R., Emanuel, K., Conabayashi, S., and Bakkensen, L. 2012. The impact of climate change on global tropical cyclone damage. Nat. Clim. Change, 2 (3), 205-209.

National Hurricane Center (NHC). Costliest U.S. Tropical Cyclones Tables Update. NOAA. 26 January 2018. 